\title{
Impact of 3 Common ABCA1 Gene Polymorphisms on Optimal vs Non- Optimal Lipid Profile in Greek Young Nurses
}

\author{
Apostolia Marvaki ${ }^{1,2,}$ Vana Kolovou ${ }^{1}, N_{i k i}, K_{a t s i k i}{ }^{3}$, Maria Boutsikou ${ }^{2}$, Anastasia Kotanidou $^{4}$, \\ Stylianos Orfanos ${ }^{5}$, Gerasimos Filippatos ${ }^{6}$, Katerina Marvaki ${ }^{7}$, Anastasios Koumoulidis ${ }^{8}$, Sophie Mavrogeni ${ }^{2}$, \\ and Genovefa Kolovou, ${ }^{2, *}$ \\ ${ }^{I}$ Molecular Immunology Laboratory and ${ }^{2}$ Onassis Cardiac Surgery Center Athens, Greece \\ ${ }^{3}$ 2nd Propedeutic Department of Internal Medicine, Medical School, Aristotle University of Thessaloniki, Hippocration \\ Hospital, Thessaloniki, Greece \\ ${ }^{4} 1^{\text {st }}$ Department of Critical Care Medicine and Pulmonary Services, Medical School of Athens, Greece \\ ${ }^{5} 2^{\text {nd }}$ Department of Critical Care Medicine, Medical School of Athens, Greece \\ ${ }^{6} 2^{\text {nd }}$ Department of Cardiology, Medical School of Athens, Greece \\ ${ }^{7}$ General Hospital, Katerini, Greece \\ ${ }^{8}$ Department of Cardiology, Evangelismos Hospital, Athens, Greece
}

\begin{abstract}
Objective: This study is in line with two previous ones from our group. They evaluated the influence of ATPbinding cassette transporter A1 (ABCA1) gene polymorphisms [such as $r s 2230806(R 219 K)$, $r s 2230808(R 1587 K)$ and rs4149313 (I883M)] on the human lipid profile (defined as Optimal and Non-Optimal).

Methods: The present study included 447 unrelated young women and men self-reported as being healthy and that attended the University of Nursing of Technological and Educational Institution. All subjects were genotyped and the ABCA1 polymorphisms $(R 219 K, R 1587 K$ and $I 883 M)$ were recorded. According to lipid profile [total cholesterol, triglyceride, high-density lipoprotein cholesterol and low-density lipoprotein cholesterol (LDL-C)] the subjects were separated into those with optimal lipid profile (Optimal Group, n=209) and Non-Optimal Group ( $\mathrm{n}=238$ ).

Results: No statistical differences were observed in the distribution of $R 219 K, R 1587 K$ and $I 883 M$ polymorphisms according to the lipid profile ( $\mathrm{p}>0.05$ in all cases). No statistical differences were observed in the distribution of $R 219 K$, $R 1587 K$ and $I 883 M$ polymorphisms according to sex ( $>0.05$ in all cases). However, Logistic Regression revealed that subjects with $R K(R 1587 K$ polymorphism) genotype had $69 \%$ increased risk on average of having LDL-C above normal limits as compared with those with $R R$ genotype. Similarly, subjects with $K$ allele ( $R 1587 K$ polymorphism) had $59 \%$ increased risk on average of having LDL-C above normal limits compared with those with $R$ allele.

Conclusion: These findings suggest that $R 1587 \mathrm{~K}$ polymorphism of $A B C A 1$ gene may influence the lipid profile. However, this needs to be confirmed by larger studies.
\end{abstract}

Keywords: ATP-binding cassette transporter A1 gene, high-density lipoprotein cholesterol, lipid profile, low-density lipoprotein cholesterol, polymorphisms, triglycerides.

\section{INTRODUCTION}

ATP-binding cassette transporter A1 (ABCA1) mediates the transport of cholesterol and phospholipids from cells to lipid-poor apolipoproteins. Animal and human studies have documented that defects in the ABCA1 pathway are determinants of coronary heart disease (CHD) [1].

*Address correspondence to this author at the Onassis Cardiac Surgery Center, 356 Sygrou Ave 17674 Athens, Greece; Tel: +30 210 9493520; Fax: +30 210 9493336; E-mail:genovefa@kolovou.com
Inactivation of $A B C A 1$ gene in macrophages increases atherosclerotic lesions in hyperlipidemic mice [2] and overexpressing human ABCA1 in transgenic mice retards atherogenesis [3]. Several $A B C A 1$ gene polymorphisms have been identified, such as $r s 2230806(R 219 K)$ in the chromosomal position 107620867, rs2230808 (R1587K) in the chromosomal position 106602625 and $r s 4149313$ $(I 883 M)$ in the chromosomal position 106626574. Clee et al [4] genotyped 804 Dutch men with CHD who participated in the Regression Growth Evaluation Statin Study (REGRESS) 
and found that $K$ allele carriers had decreased progression of atherosclerosis and a reduced risk of coronary events.

The aim of the study, in line with our previous work [57], was to evaluate the $R 219 \mathrm{~K}, R 1587 \mathrm{~K}$ and $I 883 \mathrm{M}$ of $A B C A 1$ gene polymorphisms according to lipid profile.

\section{MATERIALS AND METHODOLOGY}

\section{Subjects}

The genotyping of 447 Greek nurses ( $81 \%$ women) aged [median (range)] 22.5 (18.0-57.0) years that attended the University of Nursing of Technological and Educational Institution was performed. All subjects were self-reported as being healthy. The exclusion criteria were: any known chronic disease such as cardiovascular disease, diabetes mellitus, hypertension, hypothyroidism and renal or liver disease. Also, the subjects with professional exercise performance were excluded.

\section{SUBJECT SUBGROUPS}

\section{According to Lipid Profile}

All subjects were divided to 2 groups according to lipid profile [total cholesterol (TC), low-density lipoprotein cholesterol (LDL-C), high density lipoprotein cholesterol (HDL-C), triglycerides (TG) and apolipoprotein (apo) A].

We applied the Third Report of the National Cholesterol Education Program (NCEP) Expert Panel on Detection, Evaluation, and Treatment of High Blood Cholesterol in Adults, Adult Treatment Panel III (NCEP ATP III) classification of TC, LDL-C, HDL-C and TG [8]. Optimal lipid profile was defined as TC $<220 \mathrm{mg} / \mathrm{dl}$, TG $<150 \mathrm{mg} / \mathrm{dl}$, HDL-C $>40 \mathrm{mg} / \mathrm{dl}$ or LDL-C $<160 \mathrm{mg} / \mathrm{dl}$. Non-Optimal lipid profile was defined as TC $>220 \mathrm{mg} / \mathrm{dl}$, TG $>150 \mathrm{mg} / \mathrm{dl}$, HDL-C $<40 \mathrm{mg} / \mathrm{dl}$ or LDL-C $>160 \mathrm{mg} / \mathrm{dl}$.

\section{According to Genotypes}

We evaluated single nucleotide polymorphisms (SNPs) in chromosome 9 such as $r s 2230806(R 219 K)$ in the position 107620867, rs $2230808(R 1587 K)$ in the position 106602625 and $r s 4149313$ (I883M) in the position 106626574 according to lipid profile by using polymerase chain reaction (PCR) and restricted fragment length polymorphism analysis (RFLP's) (see below).

The University of Nursing of Technological and Educational Institution ethics committee approved the study. All subjects signed an informed consent form.

\section{DNA Analysis and Determination of Blood Lipids}

The ABCAl gene polymorphisms ( $R 219 K, R 1587 K$ and $I 883 M$ ) were detected using PCR and RFLP's. The PCR was performed using Taq polymerase KAPATaq.

For $R 219 \mathrm{~K}$ polymorphism the oligonucleotide primers which were used were AAAGACTTCAAGGACCCAGCTT and CCTCACATTCCGAAAGCATTA [9]. PCR was subjected to $95^{\circ} \mathrm{C}$ for $5 \mathrm{~min}, 30$ cycles of $95^{\circ} \mathrm{C}$ for $30 \mathrm{~s}, 55^{\circ} \mathrm{C}$ for $30 \mathrm{~s}$ and $72^{\circ} \mathrm{C}$ for $30 \mathrm{~s}$ and final extension to $72^{\circ} \mathrm{C}$ for 7 min, producing a fragment of $309 \mathrm{bp}$. This fragment was subsequently cleaved by EcoNI, creating fragments for R allele $309 \mathrm{bp}$ and for $\mathrm{K}$ allele $184 \mathrm{bp}$ and $125 \mathrm{bp}$, which were subjected to electrophoresis on an agarose gel 3\% and visualized with ethidium bromide.

For $R 1587 \mathrm{~K}$ polymorphism the oligonucleotide primers which were used were AAGATTTATGACAGGACTG GACACGA and TGAATGCCCCTGCCAACTTTAC [10]. PCR was subjected to $95^{\circ} \mathrm{C}$ for $5 \mathrm{~min}, 30$ cycles of $95^{\circ} \mathrm{C}$ for $30 \mathrm{~s}, 60^{\circ} \mathrm{C}$ for $30 \mathrm{~s}$ and $72^{\circ} \mathrm{C}$ for $30 \mathrm{~s}$ and final extension to $72^{\circ} \mathrm{C}$ for $7 \mathrm{~min}$, producing a fragment of $139 \mathrm{bp}$. This fragment was subsequently cleaved by BssSI, creating fragments for R allele $117 \mathrm{bp}$ and $22 \mathrm{bp}$ and for K allele 139 $\mathrm{bp}$, which were subjected to electrophoresis on an agarose gel $3 \%$ and visualized with ethidium bromide.

The oligonucleotide primers used for $I 883 \mathrm{M}$ polymorphism were 5'-GAGAAGAGCCACCCTGGTTCCAACCA GAAGAGGAT-3' and 5'- AGAAAGGCAGGAGACAT CGCTT -3 as described by Clee SM et al [4]. PCR was subjected to $95^{\circ} \mathrm{C}$ for $5 \mathrm{~min}, 30$ cycles of $95^{\circ} \mathrm{C}$ for $30 \mathrm{~s}, 65^{\circ} \mathrm{C}$ for $30 \mathrm{~s}$ and $72^{\circ} \mathrm{C}$ for $30 \mathrm{~s}$ and final extension to $72^{\circ} \mathrm{C}$ for 7 min, producing a fragment of $132 \mathrm{bp}$. This fragment was subsequently cleaved by EcorV, creating fragments for I allele $97 \mathrm{bp}$ and $35 \mathrm{bp}$ and for M allele $132 \mathrm{bp}$, which were subjected to electrophoresis on an agarose gel $4 \%$ and visualized with ethidium bromide.

\section{Statistical Analysis}

All data except for total and LDL-C deviated from normality (Kolmogorov-Smirnov test). Non-normally distributed continuous variables are shown as median and interquartile range $\left(25^{\text {th }}, 75^{\text {th }}\right.$ percentile), while total cholesterol and LDL-C concentrations are presented as mean \pm SD (Standard Deviation). All categorical variables are presented as relative (percentage) frequencies. The KruskalWallis H statistic or One Way ANOVA, where appropriate, were used to compare continuous variables among the 3 genotype groups, while the Mann-Whitney $U$ test or the Student's t-Test, where appropriate, were used to compare the continuous variables between the 2 groups of carriers. All tests were 2-sided at a significance level of $p<0.05$. Data were analyzed using SPSS ${ }^{\mathrm{TM}}$ (Version 11.5, Chicago IL, USA).

\section{RESULTS}

\section{Clinical and Laboratory Parameters}

Clinical characteristics and laboratory parameters of the study groups are shown in Table $\mathbf{1}$ and Table $\mathbf{2}$.

The polymorphisms frequency are shown in Table $\mathbf{3}$ and Table 4.

There was no difference in $R 219 K, R 1587 K$ and $I 883 M$ polymorphisms frequency according to Optimal and NonOptimal lipid profile ( $\mathrm{p}=0.49,0.29$ and 0.42 , respectively).

\section{Logistic Regression}

Subjects with $R K$ ( $R 1587 K$ polymorphism) had $68.8 \%$ increased risk on average of having LDL-C above normal limits as compared with those with $R R$ genotype [Odds Ratio (OR): $1.688, \mathrm{p}=0.010,95 \%$ Confidence Intervals $(\mathrm{CI})$ $1.131-2.520]$. Similarly subjects with $K$ allele $(R 1587 K$ polymorphism) had 59\% increased risk on average of having 
Table 1. Demographic data.

\begin{tabular}{|c|c|}
\hline Variable & Median (Range) \\
\hline Age (years) & $22.5(57.0-18.0)$ \\
\hline Height $(\mathrm{cm})$ & $166(207-150)$ \\
\hline Weight $(\mathrm{Kg})$ & $62(132-40)$ \\
\hline $\mathrm{BMI}\left(\mathrm{m} / \mathrm{Kg}^{2}\right)$ & $22.3(44.0-16.0)$ \\
\hline Waist (cm) & $88(143-48)$ \\
\hline $\mathrm{SBP}(\mathrm{mmHg})$ & $110(145-80)$ \\
\hline \multirow[t]{2}{*}{ DBP (mmHg) } & $70(90-40)$ \\
\hline & $\mathrm{N}(\%)$ \\
\hline \multicolumn{2}{|l|}{ Gender } \\
\hline Male & $87(19.4)$ \\
\hline Female & $361(80.6)$ \\
\hline \multicolumn{2}{|l|}{ Smoking } \\
\hline Yes & $175(39.1)$ \\
\hline No & $246(54.9)$ \\
\hline Ex-smokers & $26(6)$ \\
\hline \multicolumn{2}{|l|}{ Family History of CHD } \\
\hline Yes & $92(20.5)$ \\
\hline No & $296(66.1)$ \\
\hline Not Known & $59(13.4)$ \\
\hline
\end{tabular}

BMI = Body mass index, SBP $=$ Systolic blood pressure, $\mathrm{DBP}=$ Diastolic blood pressure, $\mathrm{CHD}=$ Coronary heart disease

LDL-C above normal limits as compared with those with $R$ allele (OR: 1,590, $\mathrm{p}=0.016,95 \%$ CI 1.090-2.319).

\section{DISCUSSION}

We examined the impact of the $R 219 K, R 1587 K$ and $I 883 \mathrm{M}$ of $A B C A 1$ polymorphisms as a genetic influence on the lipid profile in Greek subjects. In this context, the possible effects of the $A B C A 1$ polymorphisms on lipids or cardiovascular disease were recently evaluated in various populations such as Japanese [11] in which correlation with
Table 2. Study group lipid profile.

\begin{tabular}{|l|l|}
\hline \multicolumn{1}{|c|}{ Variable } & \multicolumn{1}{|c|}{ Mean \pm SD/Median (Range) } \\
\hline \hline Total Cholesterol (mg/dl) & $202 \pm 66$ \\
\hline LDL cholesterol (mg/dl) & $107 \pm 46$ \\
\hline HDL cholesterol (mg/dl) & $65(140-16)$ \\
\hline Triglycerides (mg/dl) & $97(523-12)$ \\
\hline Apolipoprotein A (mg/dl) & $147(200-100)$ \\
\hline
\end{tabular}

$\mathrm{LDL}=$ Low density lipoprotein, $\mathrm{HDL}=$ High density lipoprotein

HDL-C concentrations was found, Saudi [12] in which the $A B C A 1$ C69T gene frequency was higher in healthy subjects compared with diabetic patients, Chinese [13], in which $A B C A 1$ gene $R 219 \mathrm{~K}$ polymorphism was associated with ischemic stroke, Greek [5-7] in which a gender-specific effect of the $R 219 \mathrm{~K}$ polymorphism on plasma lipids was demonstrated, Turkish [14] in which a gender-specific effect of the $R 219 \mathrm{~K}$ polymorphism on plasma lipids and CHD was shown and Mexican [15] in which several European loci as well as a novel one for high TG and low HDL-C levels were identified. However, the results are still confusing.

Similarly, the possible influence of $A B C A 1$ gene polymorphisms on Alzheimer disease was previously evaluated. The relationship between ABCA1 R219K, R1587K and $I 883 M$ and Alzheimer disease has been reported in various ethnic groups with contradictory results. A metaanalysis of 13 studies involving 12,248 subjects did not support the opinion that $A B C A 1$ is a major genetic risk factor for Alzheimer disease [16].

With regard to subgroups with low HDL-C, Hodoğlugil et al. [17] reported that $R 219 \mathrm{~K}$ and $I 883 \mathrm{M}$ polymorphisms were related to higher HDL-C levels, Slatter et al. [18] found that $R 1587 \mathrm{~K}$ was overexpressed in low HDL-C individuals, whereas Frikke-Schmidt et al. [19] did not observe any association with $R 219 \mathrm{~K}$ but reported that $R 1587 \mathrm{~K}$ polymorphism was overexpressed in individuals with low HDL-C concentrations. In subgroups with high HDL-C, Kakko et al. [20] found a minor association between $A B C A 1$ polymorphisms and HDL-C levels in women, whereas Clee et al. [4] reported a non-significant trend towards higher HDL-C levels in carriers of $R 219 K$. As for TG concentrations, there is also inconsistency between research

Table 3. Genotype and allele frequencies in the whole cohort.

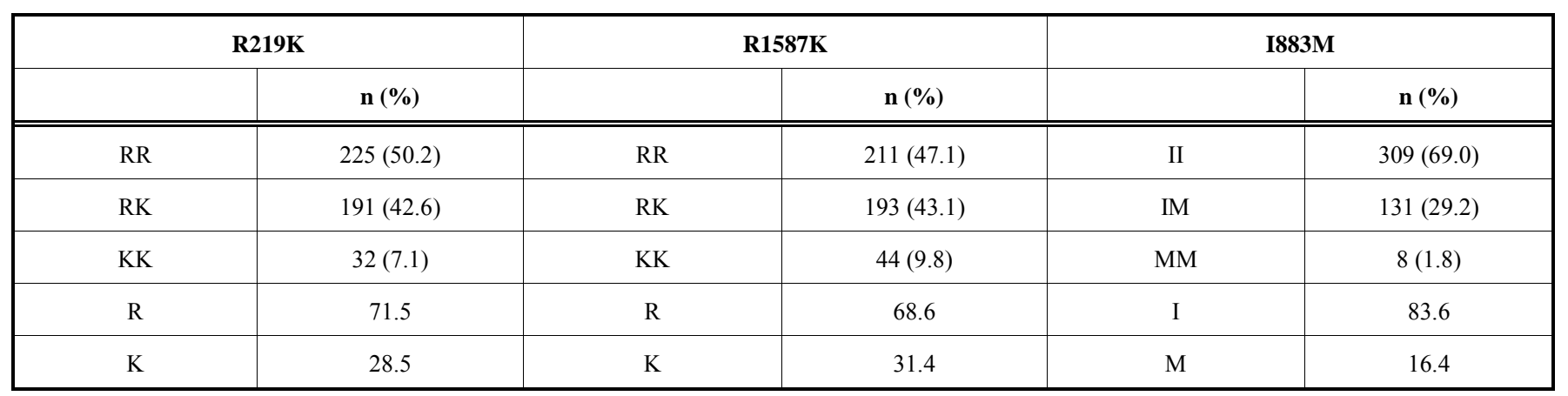


Table 4. Lipid profile according to 3 ABCA1 gene polymorphisms.

\begin{tabular}{|c|c|c|c|c|c|c|}
\hline & & $\begin{array}{l}\text { TC }(\mathrm{mg} / \mathrm{dl}) \\
\text { Mean } \pm \text { SD }\end{array}$ & $\begin{array}{c}\text { TGs (mg/dl) } \\
\text { Median (IQR) }\end{array}$ & $\begin{array}{c}\text { HDL cholesterol (mg/dl) } \\
\text { Median (IQR) }\end{array}$ & $\begin{array}{c}\text { LDL cholesterol } \\
(\mathrm{mg} / \mathrm{dl}) \text { Mean } \pm \\
\text { SD }\end{array}$ & $\begin{array}{l}\text { Apo A1 (mg/l) } \\
\text { Median (IQR) }\end{array}$ \\
\hline \multirow{4}{*}{$R 219 K$} & RR & $200 \pm 64$ & $98(523-12)$ & $66(200-25)$ & $106 \pm 45$ & $1.49(3.0-1.0)$ \\
\hline & RK & $203 \pm 67$ & $98(481-18)$ & $64(191-16)$ & $106 \pm 45$ & $1.53(3.0-1.0)$ \\
\hline & KK & $213 \pm 68$ & $95(306-37)$ & $63(126-41)$ & $122 \pm 47$ & $1.64(3.0-1.0)$ \\
\hline & $P$ value & 0.561 & 0.708 & 0.923 & 0.169 & 0.100 \\
\hline \multirow[t]{4}{*}{$R 1587 K$} & $\mathrm{RR}$ & $197 \pm 67$ & $95(481-12)$ & $65(200-24)$ & $100 \pm 45$ & $1.45(3.0-1.0)$ \\
\hline & RK & $209 \pm 61$ & $103(441-12)$ & $65(156-16)$ & $114 \pm 43$ & $1.48(3.0-1.0)$ \\
\hline & KK & $200 \pm 76$ & $85(523-25)$ & $62(155-30)$ & $108 \pm 53$ & $1.43(3.0-1.0)$ \\
\hline & $P$ value & 0.185 & 0.395 & 0.735 & 0.011 & 0.848 \\
\hline \multirow[t]{4}{*}{$I 883 M$} & II & $200 \pm 67$ & $99(523-12)$ & $65(200-16)$ & $105 \pm 47$ & $1.4(3.0-1.0)$ \\
\hline & $\mathrm{IM}$ & $205 \pm 62$ & $91(472-30)$ & $65(155-33)$ & $100 \pm 42$ & $1.5(3.0-1.0)$ \\
\hline & MM & $211 \pm 63$ & $170(321-42)$ & $68(122-41)$ & $103 \pm 38$ & $1.5(2.0-1.0)$ \\
\hline & $P$ value & 0.740 & 0.486 & 0.818 & 0.633 & 0.574 \\
\hline
\end{tabular}

$\mathrm{TC}=$ total cholesterol, $\mathrm{LDL}=$ Low density lipoprotein, $\mathrm{HDL}=$ High density lipoprotein, $\mathrm{TG}=$ triglycerides

groups. For example, Clee et al. [4] reported that carriers of $K$ allele of $R 219 K$ polymorphism had significantly lower TG levels in relation to carriers of the $R$ allele, whereas others did not find any associations. Coban et al. [14] demonstrated the interaction of TG elevation $(>140 \mathrm{mg} / \mathrm{dL})$ with CHD in female $219 R K$ genotype carriers. Delgado-Lista et al. [21] reported a trend for lower fasting TG and large TG-rich lipoproteins in minor allele carriers compared with major allele homozygotes of R219K polymorphism. In our study with young Greek nurses (living and working in similar conditions) we did not observe any association of $R 219 \mathrm{~K}$ polymorphism with HDL-C or other lipid levels, although we found that individuals with $R K$ genotype of $R 1587 \mathrm{~K}$ polymorphism had significantly higher TC, LDL-C and TG levels compared with the $R R$ genotype [7]. These discrepancies may be attributed to environmental factors such as diet, smoking and physical activities. Sandhofer et al. [22] found that $K$ allele of $R 219 K$ gene displayed a lower intima media thickness and a reduced risk of advanced plaque extent compared with non-carriers only in nonsmokers and concluded that smoking abrogates the protective effect of the $R 219 \mathrm{~K}$. Cenarro et al. [23] reported that the $K$ allele of the $R 219 K$ gene was significantly more frequent in familial hypercholesterolemia subjects without premature CHD than in familial hypercholesterolemia subjects with premature CHD and it appears to be more protective for smokers than non-smokers.

The $R 1587 \mathrm{~K}$ polymorphism is located in one of the two extracellular loops of the ABCA1 protein. This location is important for the interaction of apo A1 and for the efflux of cholesterol [19]. In our study, no association between R1587K polymorphism and HDL-C levels was found.
In conclusion, the $R 1587 \mathrm{~K}$ polymorphism of $A B C A 1$ gene was associated with altered lipid levels in young Greek nurses. Further research in larger populations is needed to establish such associations and determine their clinical implications.

\section{CONFLICT OF INTEREST}

The authors declare that they have no competing interests.

\section{ACKNOWLEDGEMENTS}

Declared None.

\section{REFERENCES}

[1] Kolovou GD, Mikhailidis DP, Anagnostopoulou KK, Daskalopoulou SS, Cokkinos DV. Tangier disease four decades of research: a reflection of the importance of HDL. Curr Med Chem 2006; 13: 771-82.

[2] Aiello RJ, Brees D, Bourassa PA, et al. Increased atherosclerosis in hyperlipidemic mice with inactivation of ABCA1 in macrophages. Arterioscler Thromb Vasc Biol 2002; 22: 630-7.

[3] Han X, Kitamoto S, Wang $\mathrm{H}$, Boisvert WA. Interleukin-10 overexpression in macrophages suppresses atherosclerosis in hyperlipidemic mice. FASEB J 2010; 24: 2869-80.

[4] Clee SM, Zwinderman AH, Engert JC, et al. Common genetic variation in $\mathrm{ABCA} 1$ is associated with altered lipoprotein levels and a modified risk for coronary artery disease. Circulation 2001; 103: 1198-205.

[5] Kolovou V, Marvaki A, Karakosta A, et al. Association of gender, ABCA1 gene polymorphisms and lipid profile in Greek young nurses. Lipids Health Dis 2012; 11: 62.

[6] Kolovou G, Kolovou V, Mihas C, et al. Cholesteryl ester transfer protein and ATP-binding cassette transporter A1 genotype alter the atorvastatin and simvastatin efficacy: time for genotype-guided therapy? Angiology 2013; 64: 266-72. 
[7] Kolovou V, Kolovou G, Marvaki A, et al. ATP-binding cassette transporter A1 gene polymorphisms and serum lipid levels in young Greek nurses. Lipids Health Dis 2011; 10: 56.

[8] National Cholesterol Education Program (NCEP) Expert Panel on Detection, Evaluation, and Treatment of High Blood Cholesterol in Adults (Adult Treatment Panel III). Third Report of the National Cholesterol Education Program (NCEP) Expert Panel on Detection, Evaluation, and Treatment of High Blood Cholesterol in Adults (Adult Treatment Panel III) final report. Circulation 2002; 106(17) 3143-421.

[9] Saleheen D, Khanum S, Haider SR, et al. A novel haplotype in ABCA1 gene effects plasma HDL-C concentration. Int J Cardiol 2007; 115: 7-13.

[10] Tupitsina TV, Slominsky PA, Yefereva YM, Perova NI, Aronov DM, Limborska SA. Linkage analysis by a transmission/ Disequilibrium of Russian sibling pairs with coronary artery disease. Balkan J Med Genet 2007; 10: 43-54.

[11] Nakamura A, Niimura H, Kuwabara K, et al. Gene-gene combination effect and interactions among ABCA1, APOA1, SR$\mathrm{B} 1$, and CETP polymorphisms for serum high-density lipoproteincholesterol in the Japanese population. PLoS One 2013; 8: e82046.

[12] Alharbi KK, Khan IA, Al-Daghri NM, et al. ABCA1 C69T gene polymorphism and risk of type 2 diabetes mellitus in a Saudi population. J Biosci 2013; 38: 893-7.

[13] Hou R, Zhu X, Pan X, Guo R, Ma T, Xu X. ATP-binding cassette transporter A1 R219K polymorphism and ischemic stroke risk in the Chinese population: a meta-analysis. J Neurol Sci 2014; 336: 57-61.

[14] Coban N, Onat A, Kömürcü Bayrak E, Güleç C, Can G, Erginel Ünaltuna N. Gender specific association of ABCA1 gene R219K variant in coronary disease risk through interactions with serum triglyceride elevation in Turkish adults. Anadolu Kardiyol Derg 2014; 14: 18-25.
[15] Weissglas-Volkov D, Aguilar-Salinas CA, Nikkola E, et al. Genomic study in Mexicans identifies a new locus for triglycerides and refines European lipid loci. J Med Genet 2013; 50: 298-308.

[16] Wang XF, Cao YW, Feng ZZ, et al. Quantitative assessment of the effect of ABCA1 gene polymorphism on the risk of Alzheimer's disease. Mol Biol Rep 2013; 40: 779-85.

[17] Hodoğlugil U, Williamson DW, Huang Y, Mahley RW. Common polymorphisms of ATP binding cassette transporter A1, including a functional promoter polymorphism, associated with plasma high density lipoprotein cholesterol levels in Turks. Atherosclerosis 2005; 183: 199-212.

[18] Slatter TL, Jones GT, Williams MJ, van Rij AM, McCormick SP. Novel rare mutations and promoter haplotypes in ABCA1 contribute to low-HDL-C levels. Clin Genet 2008; 73: 179-84.

[19] Frikke-Schmidt R, Nordestgaard BG, Jensen GB, Tybjaerg-Hansen A. Genetic variation in $\mathrm{ABC}$ transporter A1 contributes to HDLcholesterol in the general population. J Clin Invest 2004; 114: 1343-53.

[20] Kakko S1, Kelloniemi J, von Rohr P, et al. ATP-binding cassette transporter A1 locus is not a major determinant of HDL-C levels in a population at high risk for coronary heart disease. Atherosclerosis 2003; 166: 285-90.

[21] Delgado-Lista J, Perez-Martinez P, Perez-Jimenez F, et al. ABCA1 gene variants regulate postprandial lipid metabolism in healthy men. Arterioscler Thromb Vasc Biol 2010; 30: 1051-7.

[22] Sandhofer A, Iglseder B, Kaser S, Morè E, Paulweber B, Patsch JR. The influence of two variants in the adenosine triphosphatebinding cassette transporter 1 gene on plasma lipids and carotid atherosclerosis. Metab Clin Exp 2008; 57(10): 1398-404.

[23] Cenarro A, Artieda M, Castillo S, et al. A common variant in the ABCA1 gene is associated with a lower risk for premature coronary heart disease in familial hypercholesterolaemia. J Med Genet 2003; 40: 163-8.

Received: June 04, 2014

Revised: July 24, 2014

Accepted: July 28, 2014

(C) Marvaki et al.; Licensee Bentham Open.

This is an open access article licensed under the terms of the Creative Commons Attribution Non-Commercial License (http://creativecommons.org/licenses/by-nc/3.0/) which permits unrestricted, non-commercial use, distribution and reproduction in any medium, provided the work is properly cited. 